\title{
Two new tirucallane triterpenoids from Aphanamixis grandifolia
}

\author{
Xiao-Ying Wang,,${ }^{\mathrm{a}, \mathrm{b}}$ Gui-Hua TANG, ${ }^{\mathrm{a}}$ Chun-Mao YuAn, ${ }^{\mathrm{a}}$ Yu ZHANG, ${ }^{\mathrm{a}}$ Li Hou, ${ }^{\mathrm{a}, \mathrm{b}}$ Qing ZhaO, ${ }^{\mathrm{b}, *}$ \\ Xiao-Jiang HAO, ${ }^{a}$ and Hong-Ping $\mathrm{HE}^{\mathrm{a}}$ ** \\ ${ }^{a}$ State Key Laboratory of Phytochemistry and Plant Resources in West China, Kunming Institute of Botany, Chinese \\ Academy of Sciences, Kunming 650201, China \\ ${ }^{\mathrm{b}}$ Faculty of Pharmacy, Yunnan University of TCM, Kunming 650500, China
}

Received 18 July 2012; Accepted 30 August 2012

(C) The Author(s) 2012. This article is published with open access at Springerlink.com

\begin{abstract}
Two new tirucallane triterpenoids, $2 \alpha$-ethoxy-2,3-secotirucalla-2,29-epoxy-7-ene-23-oxo-3-oic acid (1) and (23E)-2 $\alpha$ hydroxytirucalla-7,23,25-triene-3-one (2), along with the known 2,3-secotirucalla-2,3;2,29-diepoxy-7-ene-3,23-dione (3), were isolated from the leaves and twigs of Aphanamixis grandifolia. Their structures were elucidated by extensive NMR and MS data, and compound 3 was further confirmed by X-ray crystal diffraction analysis. Antimicrobial activities and insecticidal activities of these three compounds were also evaluated. Compound $\mathbf{1}$ showed good antimicrobial activity against Staphylococcus aureus with the MIC value of $1.56 \mu \mathrm{g} / \mathrm{mL}$, while compounds 1 and 2 showed insecticidal activity at $100 \mathrm{ppm}$, with the corrected mortality $79.1 \%$ and $60.6 \%$, respectively.
\end{abstract}

Keywords: Aphanamixis grandifolia, Meliaceae, 2,3-seco-tirucallane triterpenoid, bioassays

\section{Introduction}

The Meliaceae family is rich in highly complicated structural secondary metabolites with significant bioactivities, which have attracted overwhelming attention in the field of natural products. ${ }^{1}$ The genus Aphanamixis (Meliaceae), consisting of 25 species, is distributed extensively in the tropical regions of Asia such as Southern China, India, Malaysia, and Indonesia. ${ }^{2}$ The roots and leaves of Aphanamixis grandifolia Blume have been applied in primitive medicine for the treatment of cold and rheumatic joints pain due to arthritis as well as numbness of limbs owing to wind-cold-dampness.

In recent years, a variety of compounds have been obtained from the genus Aphanamixis, such as triterpenes, ${ }^{3}$ limonoids, ${ }^{4}$ lignans, ${ }^{5}$ and alkaloids. ${ }^{6}$ As our ongoing research for novel structural and significant bioactive natural products from the Meliaceae family, ${ }^{7}$ three triterpenoids (see Fig. 1) including two 2,3-seco-tirucallane triterpenoids, $2 \alpha$-ethoxy-2,3secotirucalla-2,29-epoxy-7-ene-23-oxo-3-oic acid (1) and 2,3secotirucalla-2,3;2,29-diepoxy-7-ene-3,23-dione (3), ${ }^{8}$ together with a tirucallane triterpenoid, (23E)-2 $\alpha$-hydroxytirucalla7,23,25-triene-3-one (2), were obtained from the leaves and twigs of $A$. grandifolia. Herein, we described the isolation, structural elucidation, antimicrobial activities and the

*To whom correspondence should be addressed. E-mail: hehongping@mail.kib.ac.cn (H.P. He); tempzhao@126.com (Q. Zhao)

\section{照 Springer}

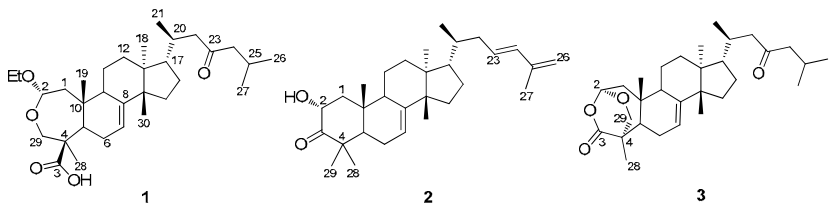

Figure 1. The chemical structures of 1-3

insecticidal bioassays of these three compounds.

\section{Results and Discussion}

Compound 1 was obtained as a colorless oil and its molecular formula was determined to be $\mathrm{C}_{32} \mathrm{H}_{52} \mathrm{O}_{5}$ with seven degrees of unsaturation due to the positive HREIMS at $\mathrm{m} / \mathrm{z}$ 516.3797 (calcd for 516.3815). The IR spectrum exhibited the existence of hydroxyl $\left(3449 \mathrm{~cm}^{-1}\right)$ and carbonyl (1755 and $1710 \mathrm{~cm}^{-1}$ ) groups. According to the ${ }^{13} \mathrm{C}$ NMR and DEPT spectra (Table 1), 32 carbon resonances were classified into eight methyls, ten methylenes including two oxygenated carbons $\left(\delta_{\mathrm{C}} 64.7\right.$ and 63.2$)$, seven methines including an acetal carbon $\left(\delta_{\mathrm{C}} 99.9\right)$, and seven quaternary carbons including a carbonyl $\left(\delta_{\mathrm{C}} 211.2\right)$ and an olefinic carbon $\left(\delta_{\mathrm{C}} 144.1\right)$. Comparison of the NMR data of 1 with those of aphanamgrandin $\mathrm{C}^{8}$ demonstrated that $\mathbf{1}$ had an additional ethoxy group $\left[\delta_{\mathrm{C}} 63.2\left(\mathrm{CH}_{2}, 2-\mathrm{OCH}_{2} \mathrm{CH}_{3}\right)\right.$ and $15.1\left(\mathrm{CH}_{3}\right.$, $\left.2-\mathrm{OCH}_{2} \mathrm{CH}_{3}\right), \delta_{\mathrm{H}} 3.79,3.47$ (each $1 \mathrm{H}, \mathrm{m}, 2-\mathrm{OCH}_{2} \mathrm{CH}_{3}$ ) and $\left.1.21\left(3 \mathrm{H}, \mathrm{t}, J=7.0 \mathrm{~Hz}, 2-\mathrm{OCH}_{2} \mathrm{CH}_{3}\right)\right]$, which was located at $\mathrm{C}-2$ through analysis of the $\mathrm{HMBC}$ spectrum. As shown in Figure 2. 1a, the seven-membered ring $\mathrm{A}$ with a carboxyl $\left(\delta_{\mathrm{C}}\right.$ $175.3, \mathrm{C}-3)$ at $\mathrm{C}-4\left(\delta_{\mathrm{C}} 50.0\right)$ was established by the HMBC 
Table 1. ${ }^{1} \mathrm{H}(400 \mathrm{MHz})$ and ${ }^{13} \mathrm{C}(100 \mathrm{MHz}) \mathrm{NMR}$ data for 1 and 2 in $\mathrm{CDCl}_{3}(\delta$ in ppm)

\begin{tabular}{|c|c|c|c|c|}
\hline \multirow[b]{2}{*}{ no. } & \multicolumn{2}{|c|}{1} & \multicolumn{2}{|c|}{2} \\
\hline & $\delta_{\mathrm{C}}$, type & $\delta_{\mathrm{H}}(J$ in $\mathrm{Hz})$ & $\delta_{\mathrm{C}}$, type & $\delta_{\mathrm{H}}(J$ in $\mathrm{Hz})$ \\
\hline $1 \alpha$ & $41.2, \mathrm{CH}_{2}$ & $1.71, \mathrm{~m}$ & $48.3, \mathrm{CH}_{2}$ & 1.20 , br. t (13.1) \\
\hline $1 \beta$ & & $2.21, \mathrm{~m}$ & & $2.32, \mathrm{dd}(13.1,6.3)$ \\
\hline $2 \beta$ & $99.9, \mathrm{CH}$ & 4.89, dd $(9.4,4.4)$ & $69.2, \mathrm{CH}$ & 4.53 , dd $(13.1,6.3)$ \\
\hline 3 & $175.3, \mathrm{C}$ & & $216.3, \mathrm{C}$ & \\
\hline 4 & $50.0, \mathrm{C}$ & & $47.3, \mathrm{C}$ & \\
\hline 5 & $54.7, \mathrm{CH}$ & $1.56, \mathrm{~m}$ & $53.2, \mathrm{CH}$ & $1.66, \mathrm{~m}$ \\
\hline $6 \alpha$ & $26.9, \mathrm{CH}_{2}$ & $1.96, \mathrm{~m}$ & $24.2, \mathrm{CH}_{2}$ & $2.04, \mathrm{~m}$ \\
\hline $6 \beta$ & & $2.31, \mathrm{~m}$ & & \\
\hline 7 & $118.8, \mathrm{CH}$ & $5.31, \mathrm{~m}$ & $117.5, \mathrm{CH}$ & $5.24, \mathrm{~m}$ \\
\hline 8 & $144.1, \mathrm{C}$ & & $145.8, \mathrm{C}$ & \\
\hline 9 & $47.1, \mathrm{CH}$ & $2.30, \mathrm{~m}$ & $48.7, \mathrm{CH}$ & $2.23, \mathrm{~m}$ \\
\hline 10 & $38.1, \mathrm{C}$ & & $35.6, \mathrm{C}$ & \\
\hline 11 & $19.6, \mathrm{CH}_{2}$ & $1.48, \mathrm{~m} ; 1.72, \mathrm{~m}$ & $18.3, \mathrm{CH}_{2}$ & $1.51, \mathrm{~m}$ \\
\hline $12 \alpha$ & $33.9, \mathrm{CH}_{2}$ & $1.64, \mathrm{~m}$ & $33.4, \mathrm{CH}_{2}$ & $1.57, \mathrm{~m}$ \\
\hline $12 \beta$ & & $1.81, \mathrm{~m}$ & & $1.73, \mathrm{~m}$ \\
\hline 13 & 43.2, C & & 43.6, C & \\
\hline 14 & 51.6, C & & $51.2, \mathrm{C}$ & \\
\hline 15 & $34.3, \mathrm{CH}_{2}$ & $1.49, \mathrm{~m}$ & 34.1, $\mathrm{CH}_{2}$ & $1.42, \mathrm{~m}$ \\
\hline $16 \alpha$ & $28.4, \mathrm{CH}_{2}$ & $1.26, \mathrm{~m}$ & $28.2, \mathrm{CH}_{2}$ & $1.24, \mathrm{~s}$ \\
\hline $16 \beta$ & & $1.91, \mathrm{~m}$ & & $1.91, \mathrm{~m}$ \\
\hline 17 & $52.8, \mathrm{CH}$ & $1.48, \mathrm{~m}$ & $52.8, \mathrm{CH}$ & $1.41, \mathrm{~m}$ \\
\hline 18 & $22.3, \mathrm{CH}_{3}$ & $0.85, \mathrm{~s}$ & $22.0, \mathrm{CH}_{3}$ & $0.73, \mathrm{~s}$ \\
\hline 19 & $11.8, \mathrm{CH}_{3}$ & $0.90, \mathrm{~s}$ & $13.8, \mathrm{CH}_{3}$ & $1.02, \mathrm{~s}$ \\
\hline 20 & $32.7, \mathrm{CH}$ & $1.99, \mathrm{~m}$ & $36.8, \mathrm{CH}$ & $1.41, \mathrm{~m}$ \\
\hline 21 & $19.4, \mathrm{CH}_{3}$ & $0.86, \mathrm{~d}(6.4)$ & $18.5, \mathrm{CH}_{3}$ & $0.80, \mathrm{~m}$ \\
\hline $22 \mathrm{a}$ & $50.4, \mathrm{CH}_{2}$ & $2.41, \mathrm{dd}(16.0,1.5)$ & $39.5, \mathrm{CH}_{2}$ & $2.20, \mathrm{~m}$ \\
\hline $22 b$ & & $2.13, \mathrm{~m}$ & & $1.73, \mathrm{~m}$ \\
\hline 23 & $211.2, \mathrm{C}$ & & $129.4, \mathrm{CH}$ & $5.56, \mathrm{~m}$ \\
\hline 24 & $52.5, \mathrm{CH}_{2}$ & $2.25, \mathrm{~d}(7.0)$ & $134.1, \mathrm{CH}$ & $6.05, \mathrm{~d}(15.5)$ \\
\hline 25 & $24.5, \mathrm{CH}$ & $2.12, \mathrm{~m}$ & $142.2, \mathrm{C}$ & \\
\hline 26 & $22.5, \mathrm{CH}_{3}$ & $0.90, \mathrm{~d}(4.3)$ & 114.0, $\mathrm{CH}_{2}$ & 4.78 , br. s \\
\hline 27 & $22.6, \mathrm{CH}_{3}$ & $0.91, \mathrm{~d}(4.3)$ & $18.7, \mathrm{CH}_{3}$ & $1.77, \mathrm{~s}$ \\
\hline 28 & $23.4, \mathrm{CH}_{3}$ & $1.17, \mathrm{~s}$ & $24.3, \mathrm{CH}_{3}$ & $1.06, \mathrm{~s}$ \\
\hline 29 & $64.7, \mathrm{CH}_{2}$ & $3.58, \mathrm{~d}(13.6) ; 4.12, \mathrm{~d}(13.6)$ & $21.4, \mathrm{CH}_{3}$ & $1.09, \mathrm{~s}$ \\
\hline 30 & $28.0, \mathrm{CH}_{3}$ & $1.00, \mathrm{~s}$ & $27.4, \mathrm{CH}_{3}$ & $0.93, \mathrm{~s}$ \\
\hline 2-OEt & $63.2, \mathrm{CH}_{2}$ & $3.47, \mathrm{~m} ; 3.79, \mathrm{~m}$ & & \\
\hline & $15.1, \mathrm{CH}_{3}$ & $1.21, \mathrm{t}(7.0)$ & & \\
\hline
\end{tabular}

correlations of Me-19 $\left(\delta_{\mathrm{H}} 0.90, \mathrm{~s}\right) / \mathrm{C}-1\left(\delta_{\mathrm{C}} 41.2\right), \mathrm{C}-9\left(\delta_{\mathrm{C}} 47.1\right)$, and $\mathrm{C}-10\left(\delta_{\mathrm{C}} 38.1\right), \mathrm{Me}-28 / \mathrm{C}-3, \mathrm{C}-4, \mathrm{C}-5$, and C-29 $\left(\delta_{\mathrm{C}} 64.7\right)$, $\mathrm{H}-1\left(\delta_{\mathrm{H}} 2.21, \mathrm{~m}\right) / \mathrm{C}-5$, and $\mathrm{H}-2\left(\delta_{\mathrm{H}} 4.89\right.$, dd, $\left.J=9.4,4.4 \mathrm{H}_{\mathrm{Z}}\right) / \mathrm{C}-$ 29, together with ${ }^{1} \mathrm{H}-{ }^{1} \mathrm{H}$ COSY correlation of $\mathrm{H}-1 / \mathrm{H}-2$. The structure of rings $\mathrm{B}-\mathrm{D}$ and the side chain moiety with a carbonyl $\left(\delta_{\mathrm{C}} 211.2\right)$ at C-23 were identical to aphanamgrandin $\mathrm{C}^{8}$. Then, the planar structure of compound $\mathbf{1}$ was established.

The relative configuration of compound $\mathbf{1}$ was deduced from the ROESY correlations. As shown in Figure 2. 1b, observed ROESY correlations of Me-19/H-2, Me-30/H-17, and $\mathrm{H}-17 / \mathrm{Me}-21$ indicated that they were cofacial and were arbitrarily assigned as $\beta$-configuration. Whereas, the ROESY cross-peaks of Me-28/H-5, H-5/H-9, and H-9/Me-18 revealed their $\alpha$-orientation. Moreover, the key correlation in the NOESY spectrum between $\mathrm{H}-2 / \mathrm{Me}-19$ suggested 2- $\mathrm{OCH}_{2} \mathrm{CH}_{3}$ were $\alpha$-orientated (see Fig 2. 1b). Subsequently, the structure of 1 was determined as $2 \alpha$-ethoxy-2,3-secotirucalla-2,29epoxy-7-ene-23-oxo-3-oic acid, namely, $2 \alpha$-ethoxyaphanamgrandin $\mathrm{C}$.

Compound 2, a colorless oil, possessed a molecular formula of $\mathrm{C}_{30} \mathrm{H}_{46} \mathrm{O}_{2}$ corresponding to its positive HREIMS at $\mathrm{m} / \mathrm{z}$ 438.3501 (calcd for 438.3498). The similarity of chemical

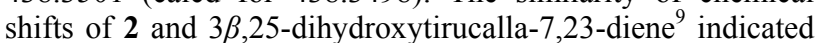
that both compounds shared the same rings system with the differences at ring $\mathrm{A}$ and the side-chain. The key HMBC correlations of Me-28 $\left(\delta_{\mathrm{H}} 1.06, \mathrm{~s}\right)$ and Me-29 $\left(\delta_{\mathrm{H}} 1.09, \mathrm{~s}\right)$ to a carbonyl $\left(\delta_{\mathrm{C}} 216.3\right)$ confirmed the carbonyl at C-3. The methine $\left[\delta_{\mathrm{H}} 4.53\right.$, dd $\left.(13.1,6.3), \delta_{\mathrm{C}} 69.2\right]$ was assigned at $\mathrm{C}-2$ by the ${ }^{1} \mathrm{H}-{ }^{1} \mathrm{H}$ COSY cross-peak of $\delta_{\mathrm{H}} 4.53 / \mathrm{H}-1$. The $\mathrm{C}-17$ side chain with conjugated $\Delta^{23}$ and $\Delta^{25}$ double bonds was established by the HMBC correlations of Me-27/C-24, C-25, and C-26, H-24/C-22, C-25, C-26, and C-27, and Me-21/C-17, $\mathrm{C}-20$, and C-22. The $\Delta^{23(24)}$ double bond was assigned as $E$ configuration by the coupling constant of H-24 $\left(\delta_{\mathrm{H}} 6.05, \mathrm{~d}, J=\right.$ $15.5 \mathrm{~Hz}$ ) together with the ROESY correlations of H-23/Me27 and $\mathrm{H}-24 / \mathrm{H}_{2}-26$.
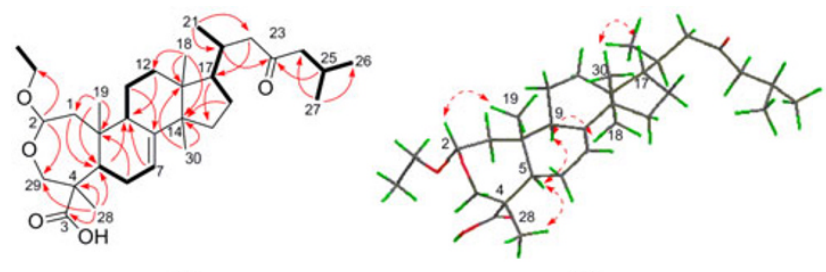

1a

1b

Figure 2. (1a) Selected ${ }^{1} \mathrm{H}-{ }^{1} \mathrm{H}$ COSY (-) and $\mathrm{HMBC}$ $(\mathrm{H} \rightarrow \mathrm{C})$; (1b) key ROESY $(\mathrm{H} \leftrightarrow \mathrm{H})$ correlations of compound 1

As shown in Figure 3. 2b, the relative stereochemistry at the chiral centers of carbons C-5, C-9, C-10, C-13, C-14, C-17, and $\mathrm{C}-20$ in 2 was determined as the same with $3 \beta, 25-$ dihydroxytirucalla-7,23-diene ${ }^{9}$ by the cross-peaks observed in its ROESY spectrum. The ROESY correlations of $\mathrm{H}-2 / \mathrm{Me}-19$, Me-30/Me-19, and H-17/Me-21 indicated they were cofacial 
and designated as $\beta$-configuration. Naturally, the $\mathrm{OH}$ group at $\mathrm{C}-2$ was $\alpha$-configuration because of the $\beta$-configuration of $\mathrm{H}-2$. Meanwhile, the ROESY cross-peaks of H-5/H-9 and H-9/Me18 indicated that these protons were $\alpha$-orientation. Thus, compound 2 was determined as (23E)-2 $\alpha$-hydroxytirucalla7,23,25-triene-3-one.
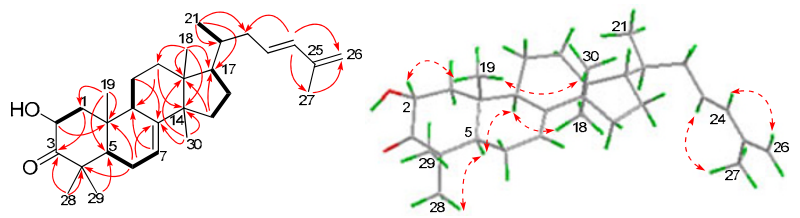

Figure 3. (2a) Selected ${ }^{1} \mathrm{H}-{ }^{1} \mathrm{H}$ COSY $(\stackrel{\text { 2a }}{-})$ and $\mathrm{HMBC}$ $(\mathrm{H} \rightarrow \mathrm{C})$; (2b) key ROESY $(\mathrm{H} \leftrightarrow-\mathrm{H})$ correlations of compound 2

The structure of compound $\mathbf{3}$ was determined by analysis of its 2D NMR spectra which was identical to 2,3-secotirucalla2,3;2,29-diepoxy-7-ene-3,23-dione. ${ }^{8}$ As shown in Figure 4, $\mathrm{H}-2, \mathrm{H}-17$, Me-19, Me-21, and Me-30 were $\beta$-oriented, and $\mathrm{H}-5, \mathrm{H}-9, \mathrm{Me}-18$, and Me-28 were assigned as $\alpha$-orientation. However, the structure of compound $\mathbf{3}$ should be the form in Figure 1 according to its X-ray crystal diffraction analysis in Figure 4 and in the literature. ${ }^{8}$

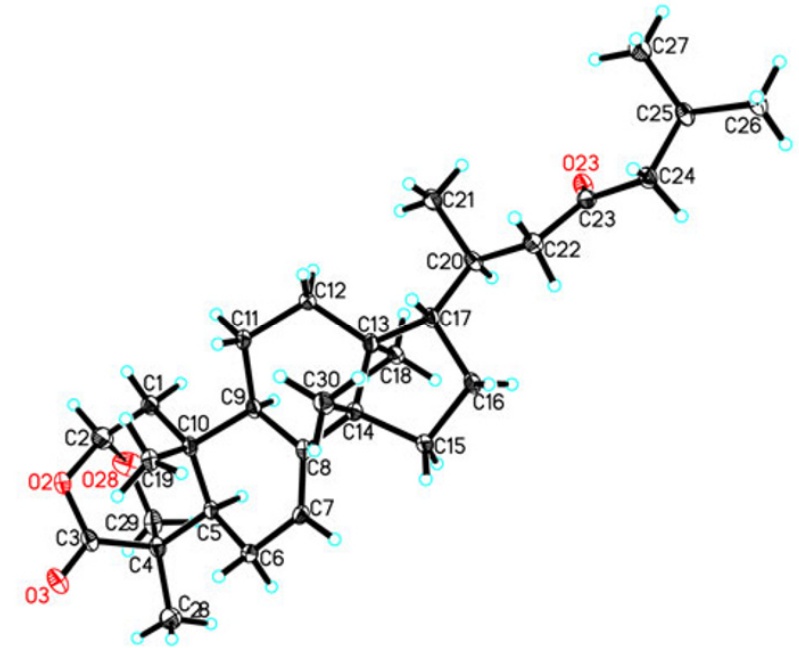

Figure 4. Single-crystal X-ray structure of compound 3

Compounds 1-3 were tested for the antimicrobial activities using a 2-fold dilution method against Staphylococcus aureus, Pseudomonas aeruginosa, MRSA (methicillin-resistant $S$. aureus) $92^{\#}$, and MRSA $98^{\#}$ with vancomycin hydrochloride (Eli Lilly Japan K. K, Seishin Laboratories, purity $\geq 98 \%$ ) as positive control (with the MIC value of $0.78 \mu \mathrm{g} / \mathrm{mL}$ to the test strains). The results revealed that compound $\mathbf{1}$ exhibited good activity against $S$. aureus (MIC value: $1.56 \mu \mathrm{g} / \mathrm{mL}$ ) and weak activities against $P$. aeruginosa, MRSA 92 (MIC value: $25 \mu \mathrm{g} / \mathrm{mL}$ for each). Additionally, compound 2 showed weak antimicrobial activities against all the four bacteria with the MIC values of $25 \mu \mathrm{g} / \mathrm{mL}$, while compound 3 showed weak antimicrobial activities against $S$. aureus and MRSA $98^{\#}$ with the MIC values of $25 \mu \mathrm{g} / \mathrm{mL}$, and against $P$. aeruginosa and MRSA $92^{\#}$ with the MIC values of $50 \mu \mathrm{g} / \mathrm{mL}$.

Furthermore, compound 1-3 were assayed in vitro for insecticidal activity against Artemia salina L. (brine shrimp) with the Microwell method. ${ }^{10}$ At the concentration of 100 $\mathrm{mg} / \mathrm{L}$, compounds $\mathbf{1}$ and $\mathbf{2}$ displayed higher corrected mortality $79.1 \%$ and $60.6 \%$, respectively (Table 2 ), while compound 3 had the lowest corrected mortality $26.0 \%$.

Table 2. Corrected mortality ${ }^{\mathrm{a}, \mathrm{b}}$ of compounds 1-3 against brine shrimp at $100 \mathrm{mg} / \mathrm{L}$

\begin{tabular}{cc}
\hline compound & corrected mortality $(\%)$ \\
\hline $\mathbf{1}$ & 79.1 \\
$\mathbf{2}$ & 60.6 \\
$\mathbf{3}$ & 26.0 \\
toosendanin & 100.00 \\
\hline
\end{tabular}

${ }^{a}$ Corrected mortality $=\left(\mathrm{M}_{\mathrm{t}}-\mathrm{M}_{\mathrm{c}}\right) /\left(1-\mathrm{M}_{\mathrm{c}}\right) \times 100 \%$. ${ }^{\mathrm{b}}$ The mean mortality of control group was $4.73 \%$. $\mathrm{M}_{\mathrm{t}}$ : mortality of treatment group, $\mathrm{M}_{\mathrm{c}}$ : mortality of control group.

\section{Experimental Section}

General Experimental Procedures. Optical rotations were measured with a JASCO P-1020 digital polarimeter. UV spectra were determined on a Shimadzu UV-2401 PC spectrophotometer. IR spectra were detected on a Bruker Tensor-27 infrared spectrometer with a $\mathrm{KBr}$ disk. $\mathrm{CD}$ spectra were obtained on a JASCO J-810 spectro-photometer. Brucker HCT/E squire and Waters Autospec Premier P776 spectrum were respectively used for measuring ESIMS and HREIMS spectra. 1D NMR and 2D NMR spectra were recorded on a Bruker AM-400 and Bruker DRX-500 spectrometer, using TMS as an internal standard. Column chromatography was performed on silica gel (200-300 and 300-400 mesh, Qingdao Marine Chemical Inc.), MCI gel CHP 20P (75-150 $\mu \mathrm{m}$, Mitsubishi Chemical Corporation, Tokyo), Sephadex LH-20 (40-70 $\mu \mathrm{m}$, Amersham Pharmacia Biotech AB, Uppsala, Sweden), and Chromatorex RP-C ${ }_{18}$ gel $(20-45 \mu \mathrm{m}$, Merck, Darmstadt, Germany). Heating thin-layer chromatography sprayed with $10 \% \mathrm{H}_{2} \mathrm{SO}_{4}$ visualized spots, which were monitored by TLC in the form of precoated plates.

Plant Materal. The leaves and twigs of A. grandifolia were collected from Xishuangbanna, Yunnan Province, China in August, 2011, which were identified by $\mathrm{Mr}$. Yu Chen, Kunming Institute of Botany, Chinese Academy of Sciences (CAS). The voucher specimen (No. H20110802) was deposited at the State Key Laboratory of Phytochemistry and Plant Resources in West China, Kunming Institute of Botany, CAS.

Extraction and Isolation. The leaves and twigs of $A$. grandifolia $(9.0 \mathrm{~kg})$ were percolated with $95 \% \mathrm{EtOH}$ three times. The EtOH distillate was concentrated in vacuum to obtain a crude residue, which was partitioned with $\mathrm{PE}$ (petroleum ether), EtOAc, and $n-\mathrm{BuOH}$, successively. The PE fraction (133.6 g) was submitted to column chromatography (CC) over silica gel (100-200 mesh) using PE/acetone (100:1 $\rightarrow 1: 1)$ to give five fractions $1-5$. Fr. 2 was separated over a whole series of CC on silica gel, MCI, RP-C 18 gel, and Sephadex LH-20 to yield compounds $1(6.0 \mathrm{mg}), 2(11.6 \mathrm{mg})$, and $\mathbf{3}(24.5 \mathrm{mg})$. 
$2 \alpha$-Ethoxy-2,3-secotirucalla-2,29-epoxy-7-ene-23-oxo-3oic acid (1): colorless oil; $[\alpha]_{\mathrm{D}}^{26}-7.0($ c $0.16, \mathrm{MeOH})$; UV $(\mathrm{MeOH}) \lambda_{\max }(\log \varepsilon) 203(2.75) \mathrm{nm} ; \mathrm{IR}(\mathrm{KBr}) v_{\max } 3449,2957$, 2927, 1755, $1710 \mathrm{~cm}^{-1}$; ${ }^{1} \mathrm{H}$ and ${ }^{13} \mathrm{C}$ NMR data, see Table 1; ESIMS $m / z 539\left[\mathrm{M}+\mathrm{Na}^{+}, 1055[2 \mathrm{M}+\mathrm{Na}]^{+}\right.$; HREIMS $\mathrm{m} / z$ 516.3797 (calcd for $\mathrm{C}_{32} \mathrm{H}_{52} \mathrm{O}_{5}[\mathrm{M}]^{+}, 516.3815$ ).

(23E)-2 $\alpha$-Hydroxytirucalla-7,23,25-triene-3-one (2): colorless oil; $[\alpha]_{\mathrm{D}}^{28}-60.2\left(c 0.06, \mathrm{CHCl}_{3}-\mathrm{MeOH}\right)$; UV $(\mathrm{MeOH})$ $\lambda_{\max }(\log \varepsilon) 205(3.10) \mathrm{nm} ; \mathrm{CD}(\mathrm{MeOH}) \lambda(\Delta \varepsilon) 285(-0.89)$, $254(-0.87), 208(-10.46) \mathrm{nm}$; IR $(\mathrm{KBr}) v_{\max } 3447,2970$, 2951, 2881, 1709, 1463, $755 \mathrm{~cm}^{-1} ;{ }^{1} \mathrm{H}$ and ${ }^{13} \mathrm{C}$ NMR data, see Table 1; ESIMS $m / z 899$ [2M + Na] ; HREIMS $m / z 438.3501$ (calcd for $\mathrm{C}_{30} \mathrm{H}_{46} \mathrm{O}_{2}[\mathrm{M}]^{+}, 438.3498$ ).

2,3-Secotirucalla-2,3;2,29-diepoxy-7-ene-3,23-dione (3) ${ }^{11}$ : colorless crystal; $[\alpha]_{\mathrm{D}}^{23}-44.8\left(c \quad 0.21, \mathrm{CHCl}_{3}\right)$; UV $\left(\mathrm{CHCl}_{3}\right)$ $\lambda_{\max }(\log \varepsilon) 273$ (2.48), $239(2.43) \mathrm{nm} ; \mathrm{CD}(\mathrm{MeOH}) \lambda(\Delta \varepsilon) 290$ $(+1.57), 212(-11.85) \mathrm{nm}$; IR (KBr) $v_{\max } 3432,2957,2925$, 2870, 1754, $1712 \mathrm{~cm}^{-1} ;{ }^{1} \mathrm{H}$ and ${ }^{13} \mathrm{C}$ NMR data, see Table 1; ESIMS $m / z 493[\mathrm{M}+\mathrm{Na}]^{+}, 963[2 \mathrm{M}+\mathrm{Na}]^{+}$; HREIMS $\mathrm{m} / z$ 470.3388 (calcd for $\mathrm{C}_{30} \mathrm{H}_{46} \mathrm{O}_{4}[\mathrm{M}]^{+}, 470.3396$ ).

Antimicrobial Bioassays. Compounds 1-3 were evaluated their antimicrobial activities against $S$. aureus, $P$. aeruginosa, MRSA $92^{\#}$, and MRSA $98^{\#}$ by the 2 -fold dilution method. ${ }^{12}$ The strains used in antimicrobial tests were obtained from the Research Center of Natural Medicine, Clinical School of Kunming General Hospital of Chengdu Military Command. The protocols of antimicrobial tests were described previously. $^{13}$

Insecticidal Bioassays ${ }^{\text {ce,7d,14 }}$. Compounds 1-3 were dissolved in DMSO and then diluted with artificial seawater to the final concentrations of $100,50,10 \mathrm{ppm}(\mathrm{mg} / \mathrm{L})$, which were added to 96-well plates with each well of 15-25 Artemia salina. After 48 hours of incubation at $28{ }^{\circ} \mathrm{C}$, the numbers of the dead (non-motile was considered dead) nauplii in each well were counted under a microscope. Each concentration was repeated in triplicate with toosendanin (Shanghai Standard Biotech Co. Ltd., purity $\geq 98 \%$ ) as the positive control, which was treated in the same way without samples. The corrected mortality was calculated by the Abbot formula.

Corrected mortality $=($ the mortality of the A. salina with sample - the mortality of the A. salina of control group) / (1 the mortality of the A. salina of control group) $\times 100 \%$

\section{Electronic Supplementary Material}

Supplementary material is available in the online version of this article at http://dx.doi.org/ 10.1007/s13659-012-0059-3 and is accessible for authorized users.

\section{Acknowledgments}

We thank Dr. Qiang Zhang, College of Science, Northwest A \& F University and Dr. Guo-Ying Zuo, Research Center of Natural Medicine, Clinical School of Kunming General Hospital of Chengdu Military Command for bioactivity testing.
This work was financially supported by grants from the National Basic Research Program of China (973 Program, 2009CB522300 and 2009CB940900), National Natural Science Funding of China (31170332), and the Young Academic and Technical Leader Raising Foundation of Yunnan Province (2010CI047).

Open Access This article is distributed under the terms of the Creative Commons Attribution License which permits any use, distribution, and reproduction in any medium, provided the original author(s) and source are credited.

\section{References}

[1] (a) Fang, X.; Di, Y. T.; Hao, X. J. Curr. Org. Chem. 2011, 15, 1363-1391. (b) Tan, Q. G.; Luo, X. D. Chem. Rev. 2011, 111, $7437-7522$.

[2] Chen, S. K.; Li, H.; Chen, P. Y. Flora of China; Science Press: Beijing, 1997; Vol. 43, Chapter 3, pp 75-80.

[3] (a) Zhang, Y.; Wang, J. S.; Luo, J.; Kong, L. Y. Chem. Pharm. Bull. 2011, 59, 282-286. (b) Liu, Q. A.; Chen, C. J.; Shi, X. A.; Zhang, L.; Chen, H. J.; Gao, K. Chem. Pharm. Bull. 2010, 58, 1431-1435. (c) Wang, J. S.; Zhang, Y.; Wang, X. B.; Wei, D. D.; Luo, J.; Luo, J. G.; Yang, M. H.; Yao, H. Q.; Sun, H. B.; Kong, L. Y. Tetrahedron Lett. 2012, 53, 1705-1709. (d) Kundu, A. B.; Ray, S.; Chatterjee, A. Phytochemistry 1985, 24, 2123-2125.

[4] (a) Yang, S. P.; Chen, H. D.; Liao, S. G.; Xie, B. J.; Miao, Z. H.; Yue, J. M. Org. Lett. 2011, 13, 150-153. (b) Zhang, Y.; Wang, J. S.; Wang, X. B.; Wei, D. D.; Luo, J. G.; Luo, J.; Yang, M. H.; Kong, L. Y. Tetrahedron Lett. 2011, 52, 2590-2593. (c) Tong, L.; Zhang, Y.; He, H. P.; Hao, X. J. Chin. J. Chem. 2012, 30, 12611264. (d) Cai, J. Y.; Zhang, Y.; Luo, S. H.; Chen, D. Z.; Tang, G. H.; Yuan, C. M.; Di, Y. T.; Li, S. H.; Hao, X. J.; He, H. P. Org. Lett. 2012, 14, 2524-2527.

[5] Sadhu, S. K.; Phattanawasin, P.; Choudhuri, M. S. K.; Ohtsuki, T.; Ishibashi, M. J. Nat. Med. 2006, 60, 258-260.

[6] Harmon, A. D.; Weiss, U.; Silverton, J. V. Tetrahedron Lett. 1979, $8,721-724$.

[7] (a) Yin, J. L.; Di, Y. T.; Fang, X.; Liu, E. D.; Liu, H. Y.; He, H. P.; Li, S. L.; Li, S. F.; Hao, X. J. Tetrahedron Lett. 2011, 52, 30833085. (b) Fang, X.; Di, Y. T.; He, H. P.; Liu, H. Y.; Zhang, Z.; Ren, Y. L.; Gao, Z. L.; Gao, S.; Hao, X. J. Org. Lett. 2008, 10, 1905-1908. (c) Yang, W.; Kong, L. M.; Li, S. F.; Li, Y.; Zhang, Y.; He, H. P.; Hao, X. J. Nat. Prod. Bioprospect. 2012, 2, 145149. (d) Liu, W. X.; Tang, G. H.; He, H. P.; Zhang, Y.; Li, S. L.; Hao, X. J. Nat. Prod. Bioprospect. 2012, 2, 29-34.

[8] Zeng, Q.; Guan, B.; Qin, J. J.; Wang, C. H.; Cheng, X. R.; Ren, J.; Yan, S. K.; Jin, H. Z.; Zhang, W. D. Phytochemistry 2012, 80, $148-155$.

[9] Luo, X. D.; Wu, S. H.; Ma, Y. B.; Wu, D. G. Phytochemistry 2000, 54, 801-805.

[10] Solis, P. N.; Wright, C. W.; Anderson, M. M.; Gupta, M. P.; Phillipson, J. D. Planta Med. 1993, 59, 250-252.

[11] X-ray crystallographic analysis of $\mathbf{3}$ : a colorless cylinder crystal (in Acetone- $\mathrm{H}_{2} \mathrm{O}$ ), $\mathrm{C}_{30} \mathrm{H}_{46} \mathrm{O}_{4}, \mathrm{MW}=470.7$. All measurements were made on a Bruker APEX DUO detector employing graphite monochromated $\mathrm{Cu}$ Ka radiation $\lambda=1.54178 \AA$ at $100 \mathrm{~K}$, and operating in the $\Phi / \omega$ scan mode. Space group P $2_{1}$ with $\mathrm{a}=$ 8.2806 (13) $\AA, \mathrm{b}=10.4107$ (17) $\AA, \mathrm{c}=15.285$ (3) $\AA, \alpha=\gamma=90^{\circ}$, $\beta=99.515(8)^{\circ}$. Crystal dimensions $0.28 \times 0.07 \times 0.07 \mathrm{~mm}, \mathrm{~V}=$ 1299.6 (4) $\AA \mathrm{Z}=2, \mathrm{dx}=1.203 \mathrm{mg} / \mathrm{m}^{3}, \mathrm{~F}\left(\begin{array}{lll}0 & 0 & 0\end{array}\right)=516$. The structure was solved by direct methods using Shelxs 97 and fullmatrix least-squares calculations. The total number of independent reflections measured was 3980, of which 3823 were observed. Final indices $\left(|F|^{2} \geq 2 \sigma|F|^{2}\right)$ : And the final agreement factors were $R_{1}=0.0712, \omega R_{2}=0.1961\left(w=1 / \sigma|F|^{2}\right), S=1.092$, Flack $x=-0.7$ (4). The crystallographic data for 3 has been

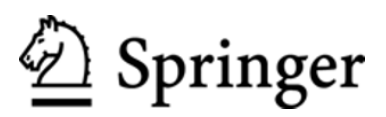


deposited at the Cambridge Crystallographic Data Centre with the deposition number CCDC 895143. These data can be obtained free of charge from the Cambridge Crystallographic Data centre via https://www.ccdc.cam.ac.uk/services/structure_ deposit/

[12] Xu, S. Y.; Bian, R. L.; Chen, X. Pharmacological Experiment Methodology, 3rd ed; People's Medical Publishing House: Beijing, 2002, pp 1647-1719.
[13] Tang, G. H.; Zhang, Y.; Gu, Y. C.; Li, S. F.; Di, Y. T.; Wang, Y. H.; Yang, C. X.; Zuo, G. Y.; Li, S. L.; He, H. P.; Hao, X. J. J. Nat. Prod. 2012, 75, 996-1000.

[14] Michael, A. S.; Thompson, C. G. Abramovitz, M. Science. 1956, 123, 464. 